Department of Economics

Working Paper Series

Does New Zealand Economics Have a Useful Past? The Example of Trade Policy and Economic Development

Geoff Brooke, Anthony Endres, and Alan Rogers

2015/08 


\title{
Does New Zealand Economics Have a Useful Past? The Example of Trade Policy and Economic Development
}

Geoffrey T. F. Brooke - Corresponding author.

Department of Economics, Auckland University of Technology

Private Bag 92006

Auckland 1142

New Zealand

+64992199995076

geoffrey.brooke@aut.ac.nz

Anthony M. Endres

Department of Economics, University of Auckland

Private Bag 92019

Auckland 1142

New Zealand

+6499237141

a.endres@auckland.ac.nz

Alan J. Rogers

Department of Economics, University of Auckland

Private Bag 92019

Auckland 1142

New Zealand

+6499237148

a.rogers@auckland.ac.nz

\begin{abstract}
We examine the history of economic thought on trade policy in New Zealand from the 1920s to the early 1980s. The focus is upon the different doctrinal perspectives taken by academic economists in New Zealand. Throughout the period under review policymakers supported an inward-looking trade and development regime buttressed by extensive interventionist trade policy. Appeals to the employment argument for industrialization through import substitution lent their policies a veneer of economic respectability. Most economists were not persuaded; they railed against quantitative import controls, discriminatory tariffs and cumbersome export incentive schemes and they offered, in vain, some constructive alternatives relying on price signals rather than administrative rules. One of our main findings is that most of the early work exposited here anticipated the rent seeking explanation for the configuration of trade policy.
\end{abstract}

Keywords: Trade Policy, Industrial Policy, Economic Thought, Rent Seeking. JEL Codes: B20, F13, N77. 


\title{
Does New Zealand Economics Have a Useful Past? The Example of Trade Policy and Economic Development
}

\begin{abstract}
We examine the history of economic thought on trade policy in New Zealand from the 1920s to the early 1980s. The focus is upon the different doctrinal perspectives taken by academic economists in New Zealand. Throughout the period under review policymakers supported an inward-looking trade and development regime buttressed by extensive interventionist trade policy. Appeals to the employment argument for industrialization through import substitution lent their policies a veneer of economic respectability. Most economists were not persuaded; they railed against quantitative import controls, discriminatory tariffs and cumbersome export incentive schemes and they offered, in vain, some constructive alternatives relying on price signals rather than administrative rules. One of our main findings is that most of the early work exposited here anticipated the rent seeking explanation for the configuration of trade policy.
\end{abstract}

Keywords: Trade Policy, Industrial Policy, Economic Thought, Rent Seeking. JEL Codes: B20, F13, N77. 
"What have been the ideas that have shaped the economic life of the Dominion, its industrial arts and economic policy? I know of no intensive and comprehensive investigation into the relation between economic-scientific thought and the economic development of New Zealand." (Hight 1939, p.4, emphasis and hyphen added).

\section{Introduction}

On the fiftieth anniversary of NZEP, it seems appropriate to repeat Sir James Hight's statement in the epigraph above —one that he made in introducing the special New Zealand Centennial number of the Economic Record containing many survey articles on the state of the New Zealand economy at that time. ${ }^{1}$ While some progress has been made since 1940 in assessing the relationship between economic analysis (Hight's "economic-scientific thought") and economic development in New Zealand (e.g. Blyth 2004, 2008; Endres 1990a, 1991), no "comprehensive investigation" has yet been undertaken. Some contributions have been made that discern definite connections between contemporary economic analysis and economic development in New Zealand (e.g. early monetary thought, Endres and Fleming 1995; exchange rate theory and policy, Fleming 1997; Marshallian economics in the first half of the $20^{\text {th }}$ century, Endres 2010). However, one of our arguments in this paper will turn on the difficulty, if not impossibility, of offering a "comprehensive" study, simply because economic analysis has more often been used as an ex post facto rationalization for developments in the New Zealand economy and for associated economic policies. As we shall maintain, sectional interests oftentimes prevailed over formal economic doctrines and economic analysis in the New Zealand case. In short, our contention is that in the example considered here, the relation between economic analysis (as undertaken by academic economists) and economic development in New Zealand has been tenuous.

Answering a variation on George Stigler's (1969) question posed in our title we can say "yes" for the New Zealand case but not for the obvious reason that simply turns on our partiality for antiquarianism. Our objective will be to supply other more compelling reasons. ${ }^{2}$ What lessons may we, as economists, learn from past contributions to New Zealand Economics? Applying Stigler's question to New Zealand economics requires some

\footnotetext{
${ }^{1}$ Hight may be regarded at the founder of academic economics and the teaching of academic economics in New Zealand (Condliffe 1950). At the very least he founded the "Canterbury tradition" in New Zealand economics from the early 1900s that was quite distinctive up to about 1940 (Endres 1991).

2 The inverted question, "Does New Zealand's past have a useful economics?" might also be posed on this anniversary, as it has been for the general case (McCloskey 1976). However, given the present paucity of specialist economic historians on New Zealand economics faculties, any answer might be delayed for some considerable time.
} 
bounds. The scope of the following discussion is confined to examining the influence of economic ideas expounded by mostly academic economists in New Zealand concerning problems and questions of economic policy and therefore indirectly relating to the development of the New Zealand economy. ${ }^{3}$ The following discussion serves as a research agenda, a prolegomenon to the intellectual history of economics in New Zealand-a field that by comparison with work of a similar nature in the Australian case is lamentably underresearched. ${ }^{4}$ The field has been given a boost by the appearance of the Biographical Dictionary of Australian and New Zealand Economists (King 2007). That book included entries on 18 New Zealand economists.

To make this study manageable our coverage is restricted to the twentieth century leading up to, but not including, the controversies among economists over the major, all-round shift in economic policy that occurred from 1984 and that has been described by the phrase "economic liberalization" (Bollard and Buckle, 1987). The prospect for a full review of the ideas of economists on various aspects of economic policy in the many decades leading up to 'liberalization' has been dormant for more than 30 years. One of the reasons for avoiding the late 1980s and the subsequent economic liberalization is that this tumultuous period in our economic history and the history of economic policy is still rather too close temporally, too raw, to enable objective assessment. Nonetheless, the legacy and development of economic ideas in New Zealand preceding those momentous changes certainly deserves attention. Some preconceptions among economists during the 1980s and 1990s may be exposed in the light of the actual history of economic thought in New Zealand. In particular we will address the oft-held view that the "reform decade" beginning in 1984 illustrated the power of what Keynes (1936, p.383) had called the "gradual encroachment of ideas" trumping the "power of vested interests" (Bollard, Lattimore and Silverstone 1996, p. 1, 6). Our examination of a selected question treated by academic economists in a more than 50 year period up to 1984, indicates that the 'gradual encroachment' thesis is not all that compelling for the case of New Zealand.

3 On this occasion we will give special mention to selected contributions of NZ economists in the Economic Record from 1925 and NZEP from 1966. The contributions of some academic economists who worked in government-appointed special commissions and committees, and quasi-government think tanks such as the Monetary and Economic Council, the Economic Monitoring Group and the New Zealand Planning Council will also be relevant. However, the role of economists and their ideas in government, even though this question is of great importance, will not be considered here. Though see McKinnon (2003).

${ }^{4}$ On the history of Australian economic thought see for example, Groenewegen and McFarlane (1990). 
One topic theme has been chosen for this study in order to illustrate our arguments and the usefulness of past economics in New Zealand: we exposit the ideas of academic economists on a rather 'large' question - the links between trade policy and economic development. Many other topics could be imagined but space limitations do not permit wider coverage. ${ }^{5}$ We offer a survey of academic economists' assessments of trade policy and major policies affecting international trade over three periods of NZ economic history prior to the mid1980s: the interwar period and trade policy issues in the Great Depression and subsequent economic recovery; the age of mercantilist thought on trade policy beginning in the late 1930s and continuing unabated in the Bretton Woods era; and the period of entrenched political resistance to trade policy changes from the 1960s to the early 1980s before the major shift toward liberalization occurred. The most salient features of economic thought on trade policy will feature in our account: tariffs; quantitative import controls; exchange controls; export subsidies; price support schemes; and active use of the exchange rate to encourage exports and/or import substitution. We will traverse a large literature. The account will be confined to the main contours of the doctrinal terrain with the intention of collecting evidence germane to one main theme: that vested sectional interests more than the encroachment of academically refined ideas dominated NZ policy formulation for most of the $20^{\text {th }}$ century. ${ }^{6}$

\section{Trade Policy Debate in Interwar NZ: Mostly About Income Distribution}

There was no self-contained trade policy or tariff debate in New Zealand equivalent to that which occurred in the UK or Australia during the first third of the $20^{\text {th }}$ century (on the UK see Winch 1969, pp.47-66; and in Australia there was the well known controversy following the Brigden Report, Australia, Committee of Enquiry 1929). However, trade policy questions arose periodically in New Zealand when consideration was being given to the dependence of national income on a narrow range of exports and export markets. It was well understood by the 1920s that there was a strong correlation between cycles and growth in national income (and fluctuations of other macro-variables such as prices, government revenues and employment) and New Zealand's foreign trade (later confirmed by Albert

\footnotetext{
${ }^{5}$ For instance there is a rich history of thought on economic crises and cycles in New Zealand; macrostabilization policy; money and monetary policy; demographic economics and economics of immigration; agricultural economics and policy; econometrics and econometric modeling; the economics of social policy; Maori economic development, and so forth.

${ }^{6}$ The full account of trade policy changes is available in Wooding (1987) and Lattimore and Wooding (1996).
} 
Tocker 1925 and comprehensively by Colin Simkin 1951 in a study of the period 18401914). Occasionally during the interwar period when national income growth markedly slowed or declined, policy issues arose concerning how to respond, including issues turning on the sectoral distribution of that fluctuating income. In this section we isolate four distinct episodes in the making of economic policy in this period that included some discussion of trade policy. We are naturally interested in the positions taken by academic economists on the subject.

(i) The National Industrial Conference (NIC) 1928: Tariff Reductions

The NIC was held to review the growing disparity between export prices and "sheltered" domestic prices and wages in a context of slow growth in national income and rising unemployment. Horace Belshaw (1928, p. 55) reported to the conference that exporters' costs were rising while returns were falling; sheltered prices were appreciably higher than they were in 1914 compared with export prices. A feature of the ensuing conference debate was the question of labour market inflexibility. The role of government wage regulation (the centralised system of "compulsory arbitration" as it was then known) was called into question; it was referenced to cost of living indices, thus often placing upward pressure on wages and in turn, other internal costs, thereby impacting on the returns to the unsheltered export sector. The State run, collective wage setting system took little account of enterprise level costs and no account of trends in exporters' incomes; it reinforced unionization at the industry level and an industry-based award system.

Five academic economists presented papers at the conference: Horace Belshaw (Auckland); Allan Fisher (Otago); Barney Murphy (Wellington); Albert Tocker (Canterbury) and David Williams (Massey). ${ }^{7}$ Apart from wage costs and wage regulation these economists commented on other costs such as the impact of tariffs on the cost of imports. Revenue tariffs were important in 1928 for public finance (indeed, they were a greater source of state revenue than income taxes), and they also included a modest protective element. ${ }^{8}$ Murphy, Tocker and Williams argued against the existing regulation of wages, while Belshaw believed that protective tariffs accentuated the disparities between external and internal prices. Belshaw (1928, p. 99) called for a "gradual reduction of the tariff" on the grounds that it "would force economies in production which are at present largely lacking. At present the tariff tends to shelter the largely inefficient businesses". Furthermore, in a paper presented jointly with the research committee of the Auckland Branch of the Economic

7 We have no space to give biographical details of the dramatis personae mentioned in this paper. For full information on the academic economists mentioned henceforth, see King (2007) and Blyth (2008).

${ }^{8}$ According to Geoff Bertram (1988 p.1), the NZ tariff structure was the "least protectionist of the British Dominions". This judgment was earlier made by Condliffe (1939) but without empirical support. See too Blyth (1974, p. 19) and Jackson (1988). 
Society of Australia and NZ (that included several academic economists, Joseph Grossmann and Edward Neale), Belshaw et. al. (1928) denied that tariff increases were a solution to unemployment even though there was some support for this idea at the conference. Citing A. C. Pigou, they played down the benefits of protective tariffs, arguing that they are an "economic cost more serious than the evils [they] attempt to remedy" (p.67).

Williams (1928) was more definite in his condemnation; he accepted the idea of a flat revenue tariff. Otherwise tariffs are a "speculative" gambit on the government's behalf aimed at assisting nonfarm employment and in many cases end up being a form of corporate welfare (p.310 not his words). ${ }^{9}$ The essence of his argument was that any further increase in the NZ tariff would have zero net economic benefit to the national economy given the country's heavy reliance on export income. Tariffs raise the cost of living for workers who then claim compensation through the collective system of wage arbitration-a system that used cost of living indices to make award determinations (p.311). At the time, the wheat and tobacco tariffs were among the highest in the tariff schedule (Bertram 1988, p.13). It took Fisher (1928 and 1932b) to point out the obvious with reference to the wheat (and thence flour) industry: farmer representatives invariably fumigated against the wage setting institutions but wanted considerable protection for wheat (and tobacco) farmers. Altogether, in the years leading up to the 1930s Depression NZ academic economists were unanimous that tariff reform was needed to assist in: lowering exporters' input costs, taking the pressure off the collectivist wage bargaining process which was referenced to the cost of living and removing inefficiencies in secondary industries. ${ }^{10}$

(ii) The Report of the Economic Committee (REC) 1932: Export Promotion

The government appointed a committee to offer policy advice on how to respond to the 192931 economic crisis, comprising four academic economists: Belshaw (Auckland), Douglas Copland (Melbourne), Hight (Canterbury) and Tocker (Canterbury), along with Alexander Park, the Treasury Secretary. The REC recommended spreading the burden of adjustment to falling external prices by revising internal prices downwards by decree: reducing money wages by $10 \%$, and fixed charges such as mortgage interest rates and bank deposit rates by a similar amount, raising sales tax by $10 \%$ and devaluing the exchange rate (experimenting

\footnotetext{
${ }^{9}$ His words: "industrial poor relief of the most uneconomic kind" (p.310).

10 James Hight was no exception. See Hight's (1928: 28-9) important paper for the League of Nations on the NZ economy.
} 
with an example of $40 \%$ ) against sterling (the official devaluation one year later was $25 \%$ ). ${ }^{11}$ As for trade policy, it appeared that the REC decided to join the contemporary currency war instead of a tariff war. No tariff changes were recommended. Instead, a discrete and major currency change was proposed as an export promotion policy. The foreign exchange market (at the time indicating considerable excess supply of foreign exchange) and the corresponding (surplus) state of the current account of the balance of payments did not warrant devaluation (Hawke 1985, pp. 133-5; Endres 1990a, p. 69). There was no explicit reference to the expenditure switching benefits of the currency devaluation; the devaluation was also an unintended import substitution policy. ${ }^{12}$ Import substitution was not fostered as a matter of policy in the early 1930s. In this period academic economists focused on ways to reduce tariffs.

Fisher (1932a) dissented from all the main recommendations of the REC and noted that tariff reform was absent from the final recommendations. He thought that it behooved NZ to go against the stream of increasing trade policy interventionism given the nation's dependence on export income. By ignoring the prospects for tariff reform the REC had opted for the politically safe route, mindful of the main local pressure groups dependent on tariff protection. Moreover, the REC had shown contempt for traditional economic analysis in formulating policy proposals that generated appeal for a populist notion that it called "equality of sacrifice". Fisher dubbed this phrase a "magic watchword" which was used to legitimate all manner of polices including the $10 \%$ wage cut (pp. 76-77). In this the REC had ignored disincentive effects on labour productivity. The wage earner is "told ad nauseam that his wages are limited by productivity" and then suddenly informed by a government committee that "his wages must be reduced...even though he has not slackened in his work" (p. 76). For Fisher, it

is impossible to realise equality of sacrifice, even if we could understand what it means. A $10 \%$ all round reduction may be necessary, but it is better to admit that the proportionate reduction of income... is merely a matter of expediency. Nor indeed...is it clear why ...we should insist on an exactly proportional wage reduction in all industries and in all industrial units. Even today there are some industries and firms in which at least normal profits are being earned, and in which therefore economic theory suggests no obvious reason why wages should be... severely cut" (p.77).

11 On the REC and the fine details of its deliberations and recommendations see Endres (1990a, pp. 67-71; 1990b, pp.4-5), Blyth (2008, pp.83-86).

12 Perhaps that was deliberate rather than unintended and therefore an accurate reading of the likely slow responsiveness of domestic secondary industry to possibilities for import substitution? Gary Hawke (1987, p. 120-21) maintains that the expenditure switching response was negligible in the following several years post-devaluation. 
This argument is prefaced by the damning criticism that the REC demonstrated "almost complete ignorance of any concrete principles upon which the distribution of income can or should be based". Indeed the REC seemed to suspend economic analysis in order to deal with "a wild scramble of conflicting interests" (p.75). By dint of its proposal for significant currency devaluation, the REC argued for a major macro-based trade policy initiative that would redistribute income to the farm sector. The REC concentrated on relative income readjustments between sectors of the economy, neglecting long-run, potentially perverse, substitution effects. The devaluation would assist in increasing the supply of resources to agriculture thus shoring up local folklore that "the best way of curbing a farming depression is to increase the number of farmers" ( $p .81$ ). And the overwhelming evidence in 1932-33 was that, in the face of increasing agricultural protectionism on an unprecedented scale, agriculture was over-producing, thereby placing ongoing downward pressure on world prices. ${ }^{13}$ Inadvertently underscoring Fisher's point, Belshaw (1933, p. 764) reported that the final official decision to devalue, taken almost a year after the REC reported, was prompted by "a large block of farmer members of the House of Representatives [that] waited on the government and insisted on the need for assistance" either through a devaluation or some "other ways".

(iii) Tariff Commission (TC) 1934: Support Imperial Preference but Reduce Overall Tariffs Barney Murphy represented academic economics on the 1934 TC. The TC review took place following the Ottawa Agreement 1932. NZ trade policy leading up to Ottawa was dominated by the motivation to keep open the UK market for NZ pastoral products almost at all costs (Sutch 1939). Thus Belshaw (1932) recommended first that NZ aim to develop comprehensive bilateral trade with the UK further reinforcing imperial preference in the process. Second, he added that all non-Empire countries should automatically be accorded imperial preference if they reduced tariffs on goods of Empire origin. As it turned out, the Ottawa conference did not favour the second part of Belshaw's proposal. Belshaw and Harold Rodwell (1932, pp. 11-12) disliked imperial preference; they thought it led to countless inefficiencies in production and trade diversion. ${ }^{14}$ In his journalistic pieces leading up to Ottawa and the TC (and in various editions of his economics textbook Outlines of Economics first published in 1924) Murphy railed against imperial preference (Bertram 1988,

\footnotetext{
13 For more details on Fisher's critique of orthodox policy proposals in the 1930s see Endres (1988). It should be added here that, well in advance of his time, in his response to the REC policy prescriptions Fisher proposed a floating exchange rate regime for NZ.

14 Thus Rodwell (1932, p.15) concluded that a "largely self-contained economic Empire stands in the path of [long-term] development".
} 
pp.20-21). Yet for Belshaw and Rodwell, in the circumstances it was a second best way to reduce protection within some regions on the way to freer trade and future multilateral trade agreements beyond the Empire.

The encouragement of intra-Empire trade had always been one of several objectives of NZ trade policy. (Not until the late 1930s was greater attention accorded to expanding the nation's tradable goods beyond empire markets through various, though not very fruitful, bilateral trade negotiations). The TC took the Ottawa Agreement as given and explicitly avoided "otiose" academic discussion about the relative advantages and disadvantages of protection compared with free trade (TC 1934, p. 8). It considered the extent and magnitude of tariffs in the light of the legislature's stated aim of "moderate protection", as the case demanded. Tribute was paid to "foreign countries" outside the Empire that might deserve favoured nation status in return for specific concessions. Tariffs were not regarded as an "emergency" policy instrument to deal with cyclical unemployment but could be justified to protect large pools of employment in particular industries and applied in the special case of infant industries (pp. 8-11). The 1934 TC saw no reason to deviate from the 1927 TC's determination that some farming activities deserved protection, especially those that produced no exportable surplus (wheat, tobacco again). ${ }^{15}$

In an interesting turn to the discussion by comparison with previous TC reviews in the 1920s, several leading international economists were quoted in this 1934 report. No doubt this discussion owes much to Murphy's involvement and we know that he drafted most of the report (Bertram 1988, p.26). The general themes from the citations of Beveridge, Salter and Taussig were that protective tariffs create "vested interests" (p.13); that the State must determine the criteria under which the "economic favour" of a tariff is granted and removed, and that tariff reviews must deal with the existing structure and not waste time considering if tariffs should exist at all. From examination of the detailed recommendations in the TC report it seems clear that two broad 'freer trade' objectives had been set:

1. Aim to simplify the existing structure of tariffs

2. Move in the direction of reducing tariffs though not only against British goods as required by the spirit of Ottawa

When the government received the TC recommendations for overall tariff reductions it ignored most of them. Those recommendations favouring reductions on British imports were generally accepted (see Bertram 1988, pp. 26-29). The government's rationale was that two bilateral objectives were served by ignoring most of the recommendations: (i) cementing

15 Tariff Commission (1927, p.6). 
access to the UK market for NZ pastoral products and (ii) maintaining high tariff premiums on non Empire countries as a bargaining tool in bilateral negotiations with those countries.

Several academic economists were highly skeptical, though Murphy remained silent on the matter. ${ }^{16}$

To use a modern term, many economists in this period drew-out the rent seeking implications of protective tariffs. The TC recommended major reductions in the tariff on wheat (then close to $100 \%$ ad valorem, Neale 1934, p.259) and flour imports. The government's decision not to act on this recommendation offers a case study in the political economy of tariffs in $\mathrm{NZ}$ at that time and it reinforces the rent seeking position. Fisher predicted this outcome. While technological advances in wheat production had reduced the international price of wheat independently of the general fall in commodity prices during 1929-31, NZ could not benefit from these improvements given the high tariff. Thus the magnitude of the tariff ensured that "whatever improvements may take place in wheat production elsewhere, New Zealand is to have no share in the benefits" (Fisher 1932b, p.269). As in the 1920s, narrow farming interests kept the NZ price of wheat well above world levels (Rodwell 1936, p.212). Fisher explained how nothing had changed since the late 1920s when a Parliamentary Committee of 10 members was charged with investigating (and recommended no change in) the wheat tariff. That Committee comprised 7 members "who represented South Island electorates, nearly all of which are actively interested in the growing of wheat" (p.262). By the 1930s, Fisher was persuaded that "the arguments in favour of taxing such people" as the masses of workers on unemployment relief partly in order to support a "key" wheat industry, were not very sound (p.268). This was especially so given that the industry was "keeping up the cost of living" for this vulnerable group, though not only this group (Neale 1934, p.259).

In retrospect, the TC 1934 failed to make much difference to the protection afforded by tariffs. Strong political pressures from the farming lobby prevented substantial change proposed by academic economists Murphy, Fisher and others. When customs duties on goods imported from Australia and Canada were subject to new, higher duties in 1938, Edward Neale (1938, p. 85) summarized the move as "giving another turn to the protectionist screw". He found it inexplicable that, in an official announcement of these increases, the government denied that prices would increase because the duties would ignite sufficient "internal competition" (p.86). The economic logic that economists in this period relied upon

16 Neale (1938, pp. 86-7) discerned the more likely reason for (ii): i.e. resistance "by pressure groups within the Dominion". Moreover Neale (1934, p.258) opined that NZ "was exceptionally badly placed for tariff bargaining" and that the high rates on non Empire countries would more likely "foster reprisals than an atmosphere conducive to negotiation". 
was essentially concerned with exposing "local industries to greater international competition" by reducing protection, thereby encouraging a mode of resource allocation consistent with the nation's "comparative advantage" (Bertram 1988, pp.25-26). All academic economists deplored the international and local drift toward greater protection in the 1930s. Local politicians pandered to the dominant rural constituencies demanding careful management of tariffs in exchange for export access to the UK market and corresponding short-term maintenance of incomes in the pastoral sector. In these circumstances, in which the use of trade policy to grow national income was secondary and the distribution of existing income the primary policy desideratum, the bulk and substance of the economists' contributions on the tariff question were destined to fall by the wayside.

(iv) Guaranteed Prices: The First Direct Export Incentive Scheme 1937

Strengthening British preference in order to secure export market access and the large exchange rate devaluation in 1933 gave some impetus to export volumes in the second half of the 1930s; they were not enough to ensure high and stable farm incomes. External prices fluctuated, as usual. That producer prices might be maintained by the State under the guise of macroeconomic "stabilisation" entered the policy agenda in the late 1930s. Before that, and not without some initial opposition from Jack Condliffe (1925), the agricultural exporters were also assisted by legislation allowing the creation of single-desk, producer-controlled marketing "boards" for all the main agricultural and horticultural products (Hampton 1933; Stephens 1936). Export licensing regulations were enacted and periodically strengthened as a form of exchange control i.e. to force the repatriation of foreign exchange receipts on a timely manner through the London bank branches of local banks (Belshaw 1933, p. 762-3; 1939b, p.179). The export control and marketing monopolies along with the licensing system reinforced the long run economic and political power of the agricultural producer boards.

The guaranteed price policy was first introduced for dairy produce in 1937 and involved considerable State subsidization. ${ }^{17}$ Belshaw $(1937$, p.170) suspected that the dairy industry scheme was a test for the eventual extension of price supports for all major pastoral products. 18 He identified several fundamental flaws in the scheme. First, the financing method was ill-considered. A dairy industry account was established at the Reserve Bank of NZ:

\footnotetext{
17 Smaller scale experiments with "guaranteed" prices occurred in the mid-1920s in the fruit industry but they were more like cooperative, price-smoothing schemes using growers' pooled resources without the large government subsidy component formulated for the dairy industry in the late 1930s.

${ }^{18}$ See also Belshaw (1939a) in which such schemes are charitably interpreted as macroeconomic instruments used in the cause of stabilizing a component of national income,
} 
From this are paid any moneys payable by the Crown in respect of guaranteed prices and costs of marketing and administration, while receipts for the sale of produce are paid into it. In short, deficits, whether seasonal or for larger periods, are to be met by an overdraft with the Reserve Bank, without limit, and without conditions of repayment (p. 172 emphasis added).

Deficits would be recorded as borrowings from the Reserve Bank and therefore represented a form of fiscal monetization with inflationary consequences (later confirmed by Belshaw 1939c, p. 79). Second, if surpluses accrued in the industry account they would be subject to intense pressure for immediate payment in election years (p.187). Third, even though economists Tocker and later Williams were involved in advising on the pricing process - $\mathrm{a}$ process that appeared to give most weight to dairy-farming cost indices - the precise method used to determine the support price was nevertheless opaque (Belshaw 1939c, p. 72-3). Apart from some of deep technical issues concerned with setting the right "price" as later outlined by Rex Bergstrom (1949), the problems do not end there. According to Belshaw, the economic philosophy underlying support for dairy product prices and dairy sector incomes paralleled the idea of State support for the share of wages in national income. So centralised wage-fixing occupied a place, as well, in this blueprint for income "stabilization". Long-held, deep-seated hankering for "equity" in sectoral income shares (recall the earlier REC concern for "equality of sacrifice" in rather different circumstances) were bound-up in the formulation of this scheme (Belshaw 1937 p.181). ${ }^{19}$ Price support schemes in other countries had often led to agricultural surpluses; they also diverted resources from other uses that could have been more productive (p.184). ${ }^{20}$ These experiences were ignored.

Altogether Belshaw finds that "it is difficult to see how the farmer can benefit without loss to the rest of the community in the long run" (p. 184). Economists were at pains to make these very points over again some 50 years later when supplementary minimum prices were introduced for the sheepmeat industry.

\section{The Economists and Planned Industrialisation 1938 -1960s: Trade Policy and the Economics of Insulationism}

though in Belshaw's view this kind of stabilisation is better achieved in conjunction with the exchange rate instrument. See too Conrad Blyth (2004, pp. 89-91) where Belshaw in 1939 is seen as having revised his earlier, very negative view of price supports.

19 Belshaw's point is confirmed in detail by Wolfgang Rosenberg (1959) who offers a case study of the period 1936-41 and explains the negotiations, and the tradeoffs made, between the level of price supports offered to dairy farmers to afford them "reasonable comfort" and periodic agreements between the government and Federation of Labour over national wage adjustments to afford wage earners a living wage.

20 Allan G. B. Fisher made these points on many occasions in the 1930s, culminating in his wellreceived book, Fisher (1935). 
The focal point of external economic policy prior to 1938 was to find ways of securing the incomes of exporters much more than it was to create a thriving labour intensive industrial sector producing import substitutes. The quantitative restrictions of imports - the import licensing scheme introduced in 1938 - marked a major shift toward the use of trade policy for long term economic development. An emerging consensus in economic thought on trade policy amongst policymakers, not academic economists, was that it was time to use trade policy as a means for saving as opposed earning foreign exchange. The dependence on foreign trade, according to the new consensus, was believed to be extreme. Trade was subject to the uncertainty and volatility of external prices and the terms of trade over which NZ had little control. There was an air of elasticity pessimism hanging over the demand prospects for traditional exports that also overlaid this policy shift. For too long in the interwar years policymakers strove to "insulate" the local economy from these price fluctuations with ad hoc responses. The verb "to insulate" underwent a subtle change of meaning in policy formulation, and became "synonymous with protection" of domestic industry (Belshaw 1939b, p.178).

There is now conclusive documentary evidence to be confident that the introduction of import controls was at once an emergency measure responding to a severe shortage of foreign reserves (in a fixed exchange rate regime) and an industry development policy aimed at import substitution and boosting employment in local industry. ${ }^{21}$ Well before the controls were implemented, one of the government's key economic advisors promoted the policy:

Quantitative regulation of imports... seems to be the device which could be chosen, not as with most European countries, merely as a means of conserving foreign credits, but a definitely purposive method of developing the national economy (Sutch 1936, p.142).

In a tone of resignation, Belshaw suggested that another approach to the foreign exchange crisis in 1938 was a reversal in the government's fiscal expansion and deficit monetization that had generated inflation and a rise in imports. ${ }^{22} \mathrm{He}$ favoured exchange rate variation because it was "administratively simple" (Belshaw 1939a, p.54, 58; 1939b, p.181; also 1939c, pp.79-80). However, policymakers rejected the price mechanism because it was not a

${ }^{21}$ See Belshaw (1939b, p.174, 178) and for detailed textual evidence see Endres (1986, pp.1921).

${ }^{22}$ Indeed L. W. Holt (1939, p.67) reviewed the evidence for the exchange crisis in 1938 and found that it was not the result of a fall in the terms of trade or major reductions in external prices. The expansionary public works programme coupled with the suppression of interest rates by the politically controlled Reserve Bank caused a surge in the propensity to import. See too, in a similar vein Belshaw (1939b) and Murphy (1939a, p.638). 
means of directly controlling the level of external reserves. Direct control over the level of reserves via exchange controls and import controls also implied central planning (via import selection) over the direction in which domestic industry would develop and control over demands for foreign consumer goods. The older export licensing system assisted the Reserve Bank's policy to commandeer all foreign exchange from exports at source; the rationing of foreign exchange through the politically dependent Reserve Bank completed the circle.

The subsequent lamentations of prominent academic economists who were favourable to older classical principles of freer trade and the international division of labour should be recounted here. Thus Belshaw (1939b, pp.181-2):

[T] here is still much to be said for the view that a distribution of resources based on comparative advantage would be more conducive to increased economic welfare than a policy which in effect...prejudices the well-being of the individual as consumer, while endeavouring to further it as a producer.

Belshaw proposed that $\mathrm{NZ}$ abandon import and exchange controls after the war in the interests of promoting freer trade not least because such controls "encourage vested interests in uneconomic industries", and crimp consumer choice. NZ urgently required diversification of its markets for tradable goods and this drove Belshaw to renew his earlier campaign against imperial preferences (Belshaw 1941, pp.421, 439-41; 1947, p.136). At most, the 1938 controls should only be regarded as "temporary" post-war recovery measures (Belshaw 1945, p. 52-3). As well, Barney Murphy (1939 a, b, c) inveighed against the new policy of import and exchange control that, broadly consistent with one tenet of mercantilist doctrine, jettisoned the principle of comparative advantage. For Murphy the policy shift was all about the "drive for a greater measure of economic self-sufficiency through manufacturing expansion". Such expansion was likely to result in the establishment of industrial units with sub-optimal scale, isolated from international competition, without much incentive to adopt technological advances and producing poor quality outputs (Murphy 1939b, p.680; 1939c, p.842). Import selection for industrial development required deep knowledge of local resource supplies and costs of production. Indeed the problem of selection "cannot be solved by Ministers of the Crown making goodwill visits to factories... and having their boots kissed (metaphorically) by obsequious manufacturers, and their faces kissed (literally) by enthusiastic female employees" (p.836). Murphy understood that import selection problems were largely solved by two well-organized pressure groups: manufacturers and trade unions seeking profit and employment protection, respectively. Consumers were not so organized. An inward-looking, nationalist policy stance had come into vogue emphasizing foreign exchange saving, import substitution and short-term employment maximization. It promised to become a "permanent feature of national life" 
(Murphy 1939a, p.638). Previous dependence on external forces which brought with it "insecurity" in real incomes earned by various sectional interests in the economy, would be blunted by policies that create a more insulated economy. As Fisher (1935) maintained in a summary judgment, such policies adopted in the interests of greater national economic security would trade-off against the rate of economic growth.

Post-war, and following the Bretton Woods agreement, NZ trade policy did not change fundamentally. The fixed nominal exchange rate regime was maintained. NZ did not immediately join the IMF in 1945 though it became a de facto participant in the Bretton Woods system. The plan neither to remove import controls and replace them with tariffs nor gradually liberalize current account transactions militated against joining the IMF. At the very least, NZ politicians feared the loss of sovereignty over these policies as reasons for delaying membership until 1961 (Hawke 1972, pp. 93-4; Holmes 1996, p.11). Thus in a major balance of payments crisis of the kind that occurred in 1958, NZ could not rely on IMF adjustment finance, or any international finance for that matter. Instead import controls were extended and deepened precisely because of the international liquidity constraint (Endres and Rogers 2014, p.68). This is just as we would expect in a policy framework based on selfsufficiency. And leading academic economists continued their heavy criticism of that framework. Colin Simkin's (1946) inaugural address at the University of Auckland, "Insulationism and the Problem of Economic Stability", was an exemplar in this respect. $\mathrm{He}$ defined "insulation" more broadly than Belshaw; it was concerned with any economic policy that would insulate the NZ economy from internationally transmitted business cycles. The policy aim was to "reduce cyclical fluctuations" and achieve "full employment" (Simkin 1946, p.51). Four main instruments of that policy are identified:

1. Counter cyclical fiscal policy

2. Guaranteed prices for agricultural outputs

3. Exchange controls

4. Development of "self sufficiency" using import controls

Altogether these instruments relied upon a "clumsy and rather arbitrary system of state regulation" (p. 51). The resultant economic policy combination of the four instruments focused on protecting a given level of national income. Thus external economic policy, instruments 3 and 4 (and possibly 3 if it is regarded as an export incentive scheme), was not primarily concerned with actively growing export earnings and national income. The "full benefits of the international division of labour" are sacrificed. Any excesses or failings in the application of the first two instruments required 3 and 4 as backup. For example the propensity to import may be dampened by tightening the import license rules as the situation demanded. 
Simkin warned that the extent to which locally produced goods were not as efficiently produced as imports they displace was uncertain and untested. In any event, he expected that real national income would be lower than it could have been without import controls; the import selection policy tended to rigidify the economic structure since administrative rules were less flexible than the price mechanism in allocating resources. The joint effect of the four policy instruments may maintain full employment but long run stability in employment was not assured and a "permanent inflation problem" could arise. Broadening and dramatizing his critique, Simkin cited Friedrich Hayek's Road to Serfdom in likening the NZ the import and exchange control schemes to interventionist meddling that risks "weakening the rule of law in favour of arbitrary, and possibly capricious bureaucratic regulation" (p.61). There were hints here of an earlier paper while he was on the Canterbury faculty, explicitly inspired by Karl Popper, in which he condemned all forms of "collectivist planning" because they were "destructive of economic efficiency as well as of liberty and reason" (Simkin 1945, p.12). ${ }^{23}$

Alternative policy instruments were proposed in Simkin (1946, pp.64-5). First, NZ should join the IMF and utilize IMF foreign exchange loans for temporary current account deficits, thereby easing the foreign exchange constraint and obviating the necessity to tighten import controls and raise tariffs at the first sign of a balance of payments problem. Furthermore, if the current account problem became more long-term and persistent, the exchange rate could be used in the IMF-governed Bretton Woods system. Second, abolish import controls and, if that was politically unpalatable, at the very least design a competitive bidding system for the privilege of obtaining import licenses. He maintained this position after analysing trends in NZ's balance of payments for 1948 and 1949 and showed that external balance could be reached without import controls (Simkin 1951). Third, use a uniform tariff instead of attempting to identify particular industries that deserved more or less protection. The idea in keeping the rate of tariff protection uniform was that the policy does least harm; it would not negate the principle of comparative advantage. Import substitution would then favour industries with the least comparative disadvantage. It took many decades before these ideas were given serious consideration by policymakers. Overall, in his inaugural lecture for the chair in economics in one of NZ's leading universities, Simkin challenged the whole basis of external economic policy. It was a far-sighted critique that fell on deaf ears.

23 Simkin was strongly influenced by Karl Popper while they were both at Canterbury. Specifically, Simkin (1945) reflected Simkin's early access to Popper's manuscript of The Open Society and its Enemies, published later that year. Popper (1945, p. x) acknowledges Simkin's contribution to that work. 
The external policies in place in the later 1940s owed little to "theoretical considerations" and much more to "safeguarding the existing position of important groups". For Simkin there was no sound economics acting as a basis for "insulationism" as practiced in NZ. A "precious policy of self sufficiency" enjoyed primacy (Simkin 1948, p. 31). The most efficient allocation of resources and the adaptability of the NZ economy to change-both necessary for long- term growth in domestic incomes-were missing from the policy agenda. In addition, careful empirical investigation of resources, markets and comparative costs had not been undertaken to justify that agenda. Without independently verifiable evidence, in the early post-war years policymakers asserted the need for continuing, unaltered protection of local industries from trade with both low labour cost countries and industrialised countries using methods of mass production (John Williams 1948, pp.98-9).

Later, in the first Sir Sidney Holland Memorial lecture, Rodwell (1959, p.14) identified the vital role of export pessimism that was carried over from the pre-war years into the 1950s, such that "saving overseas funds" took precedence over thinking about how to expand export incomes. ${ }^{24}$ This was a general empirical judgment that pervaded both policy formulation and policy inaction as far as external trade was concerned; it had no sound basis in principle just as Simkin had argued a decade earlier. Moreover, it did not seem to matter therefore, that export industry investment had been handicapped so as to support many manufacturing industries "which can survive only behind the impregnable barrier of import or exchange controls" (Simkin 1953, p. 9). In the third Sidney Holland Memorial Lecture, Frank Holmes (1962, p. 26) pointed to another alarming problem: the instruments of economic policy were not independent of one another in their application and effects. Frequent changes in fiscal policy occurred in the 1950s and led to wide variation in the flow of imports. In particular, the system of import controls and exchange controls was not flexible enough to react to short-run excess demand; and this flexibility was constrained by vociferous industry interests, locked-in to depending on licenses for imported materials. Thus a splendid irony: the very instrument that was meant to ease difficulties in the current account of the balance of payments had "been much more important" in exacerbating those difficulties in comparison with the usual bogey - the variability of overseas export earnings.

24 Export pessimism was widespread in developing countries at the time. It was based on the premise "that both the global income and price elasticities of demand for primary commodities were low. Consequently, it was anticipated that export earnings would not grow very rapidly, if at all" (Krueger 1997, p. 3). 
New Zealand trade policy in the 1950s led to an uneven allocation of resources biased toward saving a unit of foreign exchange with the prime objective being full employment. The extension of import licensing in 1958, according to the NZ Treasury $(1958$, p.58) was "a short-term solution to the problem of maintaining external solvency while at the same time ensuring that priority was given to essential imports on which the condition of full employment depended". Again academic economists suggested that NZ use the exchange rate instrument and tariffs, both of which allowed room for market prices and market competition to meet the employment objective on a longer time frame (e.g. Copland 1960, p.5). ${ }^{25}$ That NZ trade policy was founded on the premise that individuals, producers and firms only weakly respond to price incentives was not unusual at this time; it was quite common in a developing-country context (Krueger 1997, p.4). However, NZ was not really a "less developed" country as Massey University economist Wilf Candler (1963) pointed out; he caricatured economic policy formulation in NZ as attempting to "progress backward" toward an insular, traditional economy by eliminating market incentives wherever possibleand toward an economy 'less developed' in the sense that it did not place much store by growing per capita, material incomes. Existing trade policy featured in his discussion; he demonstrated how the various dimensions of that policy were subordinated to the goal of full employment "which the community is willing to pursue at, literally, any cost" (p.876). ${ }^{26}$

A common theme in work of academic economists in the period from the late 1930s to the 1960s was not confronted squarely by proponents of planned industrialization prosecuted by a protectionist configuration of trade policy. That common academic theme turned on the likelihood that import licensing in particular, but also over-zealous application of exchange controls and discriminatory tariffs, would reduce the standard of living in NZ, including real wages, for a very long time, if not indefinitely. In reflecting on the economic liberalisation occurring after 1984, Conrad Blyth (1987, p.19-20) gave this theme authoritative expression. In Blyth's retrospective, NZ trade policy based on planned industrialization had generally been used as "a device to reduce the standard of living (i.e. real wages)" though it was not often recognized in these stark terms.

25 This advice was similar to his recommendations following the initial implementation of import licensing (Copland 1939, p.30). Douglas Copland, an expatriate NZ academic economist, was on a visit to NZ in 1960 and made the following remarks worth quoting here: "outside the field of sports...our scale of values gives competition a low priority. In the economic field in New Zealand the spirit of competition is weak...New Zealand is at the stage where its manufacturing must meet the comparison of the world...Unless we have price competition with the resultant search for lowering costs we end up with lowering living standards" (Copland 1960, p. 9-10). 26 The preeminent position given to full employment may explain the framing of trade policy in the 1950s but the official time frame for achieving that goal was opaque (Endres 1984). 


\section{Academic Economists on Trade Policy Problems and Prospects for Reform: 1960s-} 1980s

The complete overhaul of economic regulation in NZ and the reform of trade policy in the direction of a more open economy was never likely to become government policy in the 1960s despite the continued protestations of Simkin (1962). Blyth (1964, p.15) captured the mood of the times: "New Zealanders and their government...do not like the operation of free markets, and particularly in the interests of important pressure groups attempt to manage or even dispense with markets". In effect, the "important pressure groups" included the main beneficiaries of state intervention in the economy: producers interests sheltered behind the wall of trade controls, and wage earners who enjoyed both the employment protection of those controls and the policy of centralized wage-fixing. In this context trade policy was extended in the early 1960s to help manufacturers develop a variety of new export markets with the help of export incentives. Indeed, NZ began to build what, by the late 1970s, became a highly discriminatory, complex set of approximately twenty different export incentive schemes (Lloyd et al. 1980, pp.96-113; Wooding 1987, pp.88-9). ${ }^{27}$ Certainly academic economists had given indirect impetus to export incentives in their earlier work if only, as we have seen, because they underscored the need for policy to focus on the need to earn foreign exchange.

Several institutional initiatives in the early 1960s gave legitimacy to the 'earn more foreign exchange' message - the Industrial Development Conference (IDC) in 1960, the Export Development Conference in 1963 - both lent support to the idea of "manufacturing in depth" for eventual expansion into export markets (Endres 1986, pp.28-30). As well, under the leadership of Blyth and Holmes respectively, the NZIER was established (and turned its early research attention to the interconnected problems of manufacturing development and growth in NZ), and the Monetary and Economic Council (MEC) began its regular reporting to the Minister of Finance (and turned its early attention to economic growth and the problem of growing foreign exchange earnings). Widening NZ's export base became a major question in policy discussion partly because of the fear of losing free access to the British market for traditional exports. Frank Holmes (1958, 1959a) was an ideational frontrunner analyzing ways NZ could negotiate in the EEC context and develop new trading arrangements outside that geographical area. At the IDC Holmes (1960, p. 6) tactfully reminded policymakers that as a signatory to the GATT, NZ had accepted "a desirable bias toward freer trade".

Moreover, NZ must therefore have accepted the GATT "in principle...bans [on] the use of

27 This set of schemes did not include direct production subsidies to farmers of various kinds, culminating in the generous supplementary minimum price scheme for meat production in the late 1970s. On these subsidies see Lattimore and Wooding (1996, p.326). 
quantitative restrictions for protective purposes". He explained that the only exception was that quantitative restrictions are permissible temporarily to restore a nation's foreign exchange reserves. Perhaps Holmes was too polite, because NZ had maintained those restrictions from 1938, and strengthened them again in the 1950s.

The older preoccupation with economic security and stability dissipated in the 1960s but as before the focus was on what government could do to diversify export markets and enhance export earnings of non-traditional, manufactured products (MEC 1962, 28-30; Blyth 1963, Tariff Board 1963). The consensus favoured adding another layer of government interventions (export incentive schemes) on to an already heavily regulated economy. Alternatives were not taken seriously, especially those that meant choosing the price mechanism (e.g. a more flexible exchange rate) and a more "liberalised environment within which the economy might develop, with no quantitative import licensing and no discrimination in tariffs" (Blyth 1964, p.15). ${ }^{28}$ In principle, the choice to encourage export earnings could have taken another route-reducing the implicit tax on exports (the higher domestic costs imposed on export industries) arising from a trade policy that gave preeminence to import substitution. This alternative choice was proposed by Bryan Philpott (1964, p.29), who asserted that import licensing had reduced the rate of growth of traditional exports.

The economic logic for Treasury-financed export incentives seemed sound enough from the standpoint of the recipients. They were (i) quid pro quo for a fixed exchange rate and therefore, from time-to-time, a rate that did not lend itself to encouraging long-term risky production plans in the manufacturing sector aimed at diversifying export markets; (ii) compensation for the implicit tax on manufacturer's operations arising from import controls that increased the domestic cost of intermediate goods used by exporters and (iii) an incentive to diversify the composition of exports and export markets in order to grow foreign exchange earning (owing to the external liquidity constraint attributable to the self-imposed yoke of controls on private capital inflows, Endres and Rogers 2014). The more private capital inflows were crimped by regulation the greater the need to achieve import savings and expand exports. It was several decades after the first export incentive schemes that long experience of such schemes in NZ revealed many serious flaws and ill-considered implications (Cullen and Wooding 1981). Fiscal costs, and more so the displacement effects

\footnotetext{
28 To be sure, Holmes and other academic economists wanted to suggest using the exchange rate more often but as he recalled later, "these were the days when it was irresponsible to advocate that publicly" (Holmes 1994, p. 9; see too Holmes 1959b). We imagine that his comment might also have applied to advocating use of the price mechanism in general.
} 
of additional fiscal outlays, were generally regarded as minor. The fact that the Export Licensing Incentive Scheme in particular encouraged expansion of goods for export with high import content conflicted with the balance of payments objective of saving foreign exchange and made the import licensing regime somewhat redundant. Rent seeking was rampant from the first scheme in the early 1960s. Of course the formal literature on this subject came later (Krueger 1974). The first schemes were constructed in close consultation with the Manufacturer's Federation - a principal beneficiary of the subsidies. The "manufacturer's lobby" as Ross Cullen and Paul Wooding (1981, p. 146-7) described it, made submissions to the Tariff Development Board on the criteria and goals that should be adopted for NZ's industrial development in the 1960s. These were officially accepted; meeting those criteria required export incentives (Manufacturers Federation 1963, Tariff Development Board 1963, p.91).

Some early work on the econometrics of elasticity of supply in NZ's farming sector might inadvertently have lent support to the overall climate of elasticity pessimism relating to traditional agricultural export-potential. This could also help explain the turn in favour of providing government support for the cause exporting non traditional exports in the 1960s. Both Rex Bergstrom (1955) and Robin Court (1967) report very weak and in some cases even negative responsiveness of agricultural supply to price changes. Later Grant Scobie (1973) produced quite optimistic results on the demand-side, though Bob Buckle (1977) and Nicola Blyth (1983) countered with mixed if not ambiguous conclusions. All these studies were undertaken in an existing economic-regulatory (as opposed natural, farming) environment affecting agriculture in $\mathrm{NZ}$ - a regulatory environment not all that conducive to rapid farm supply responsiveness. Even if elasticity estimates were approximately correct, they were hardly relevant in different institutional conditions. For instance, we might mention the 'tax' on farm intermediate goods inputs due to border protection; highly regulated labour, capital and transport markets; severe restrictions on external capital inflows; uncompetitive fertilizer markets and so forth. In these circumstances sluggish supply response was perfectly understandable.

As had been advocated so often prior to the 1960s, another way toward overcoming the bias against export expansion was to reform the external protection regime. Empirical work on the impact of the existing protective structure in $\mathrm{NZ}$ was scarce. By comparison, in Australia at this time, Max Corden's $(1963,1966)$ well-known concept of the "effective rate of protection" was operationalised in several studies applied to the Australian tariff regime. In NZ, the idea was broadly understood. The methods used in calculating the costs of protection were controversial given the dominance of import licensing over tariffs in the NZ 
case. Wilf Candler and Peter Hampton (1966) contributed an early, exploratory attempt at calculating the cost of protection in NZ (following Corden). More thorough studies had to wait until the 1970s (e.g. Elkan 1972, 1977; and studies of the effective rates of subsidy in various export industries, e.g. Makin 1983). Cullen and Wooding (1981, p. 154), like others before them dating back to Simkin in 1946, alluded to the possibility of making import licenses tradable; that they were still not tradable in 1981 again reflects the viewpoint that trade policy in the period under review was captured by a virulent form of rent seeking. The rationale for entrenched political opposition to reforming quantitative import controls has to be sought not in the work of economists over this period from 1960 to the early 1980s; the political economy dimension was far more decisive.

It was finally established by economists in the 1960s that the NZ trade policy concentration on industrial protection and import substitution, was an abject failure. First, the periodic election-year fiscal largesse noticed in the 1950s and again in the 1960s, overrode the policyplan to reduce import reliance. Import demand surged in those years despite the controls and the balance of payments on current account deteriorated in some years to the point of "crisis" (e.g. Zanetti 1966). The long-term measurement of changes in import reliance produced sensational results (Rowe 1966; Brownlie 1966). A subtheme of the elasticity pessimism story from 1938-1960s was that the terms of trade for NZ's agricultural exports would weaken inexorably on a secular basis; hence best to work on ways to reduce import reliance in the meantime. John Rowe (1966) brought to bear new data and techniques to measure import reliance from 1950-65 and found that the various instruments used to discourage imports did not effect any significant change in the ratio of external expenditure to real GNP. Bert Brownlie (1966, p. 20) commented on the results and implications:

We have been unable to refute Mr. Rowe's surprising conclusion; surprising because an ostensible purpose of import controls and industrialization in New Zealand has been to reduce the country's import reliance. A factor which has probably contributed to this result is the governments' tardiness in using price and profit incentives to bring about changes in the structure of demand and production which lower import dependence.

The profitability of protected firms in the home market did not depend to any great extent on cost considerations and those firms were not disciplined by competition with imports. Rowe (1966, pp.26-29) offered some telling insights in interpreting his results: NZ's combination of tariffs and quantitative controls engendered a greater degree of inflation than previously understood; they reduced domestic product market competition by conferring monopoly power to license holders in the home market; created many firms of sub-optimal size and reduced productivity growth. Of course the last three factors were not unrelated to the 
inflation outcome. Most of the above observations had previously been made by NZ economists but without much empirical evidence. Employment was created in the manufacturing sector but it was of poor quality (see also Les Castle 1966). We are then treated to (the now familiar) suggestions for reform including the removal of quantitative controls and the creation of a uniform ad valorem tariff to eliminate the unevenness of protection. ${ }^{29}$ As we should expect, policymakers, existing producers and trade unions benefitting from the controls, remained steadfast in their opposition to reform in the trade policy realm.

So where does that leave us in terms of the policy of planned industrialisation? For Wolfgang Rosenberg (1972, p.53), contra Rowe and Brownlie, this policy worked to "defend New Zealand full employment against foreign induced balance of payments fluctuations" and should be retained for that reason alone. Rosenberg was a staunch defender of the Raul Prebisch model of economic development formulated for less developed Latin American countries, applying that model to the NZ case throughout his academic career (Rosenberg 1964, 1965). ${ }^{30}$ He rejected the principle of comparative advantage on the grounds that if taken seriously it would trap NZ indefinitely in primary production, without sufficient secondary industry to employ its growing population. Rosenberg (1972, p.78-9) asserts that "import controls have assisted in the industrialization of New Zealand.... We have established industries which could make things formerly imported". The next task (post-1972) "must be one of building up export earnings" with considerable government financial and technical assistance. By then the die had been cast in NZ academic economics against Rosenberg's position. Conrad Blyth's (1974) inaugural lecture on "The Industrialisation of New Zealand" was important not only because it broadly confirmed the skepticism of many earlier economists on the lack of potency of government intervention to protect and industrialise the economy; it was delivered at a time of high employment and strong terms of trade, thereby enabling policymakers an opportunity to dismantle (if they wished) the old trade policy in favourable conditions when labour and capital might more readily move to better uses. In taking a long view of industrialization in NZ from the mid-19th century to the 1970s and classifying domestic processing of primary products in the manufacturing (or

29 Jack Condliffe, on an extended visit to NZ in 1968-9 on leave from the University of California Berkeley, produced The Economic Outlook for New Zealand (1969) in which he concluded that New Zealand economic policy overall was based on "government of producers, by producers, for producers" (p.116). In terms of trade policy he argued that the import substitution approach had failed and was adamant that "the result of import restriction is a net cost to the consumer and a net diminution of available foreign exchange" (p. 120)

${ }^{30}$ For a critical response to Rosenberg's approach by his Canterbury colleagues see Hampton, Hudson, Miller and Tay (1964). 
"secondary industry") category, Blyth doubted whether NZ had much control over its "industrial destiny". Allowing for the depression years, Blyth demonstrates that "the rate of growth of manufacturing production has been remarkably steady". The same conclusion applied to labour productivity in that sector (p.12). Industrial developments concerned with processing of primary products in particular "has been consequent upon foreign trade" (p.13). Altogether, the "natural forces of falling relative wages" compared with the rest of the world, along with "expanding domestic markets" with the growth of population, have been responsible for the steady expansion of non primary industries. Changing (or entrenched) trade policy frameworks did not seem to matter much perhaps because of the strong dependence on one major external market for exports throughout the approximately 130 year period? More concerning for those wedded to extant industry protection policies with the employment objective in mind, is his finding that "the trend rate of growth in secondary manufacturing employment shows no distinct break since the First World War". While the counterfactual is not easy to test, Blyth maintains that at the very least, the major shift of trade policy in 1938 toward "self sufficiency" (to use Simkin's earlier term) did not seem to accelerate the employment trend in the following decades when that policy became entrenched (p.18). ${ }^{31}$

One of the risks in accepting Blyth's position post-1974 is that it could lead to policy apologetics - to accepting, for instance, the short run distortions, rent seeking and other costs of the existing regime of interventionism in NZ given that its strength and effectiveness in achieving objectives (e.g. high employment) would likely be minimal in the very long run. In fact, the consensus on trade policy had not shifted far in the 1970s except in respect of freer trade with Australia — an idea originating in the work of Frank Holmes in the 1960s (Holmes 1961, 1966 and 1994, pp. 10-12). Holmes led the MEC from the early 1960s and in 1962 it recommended more research on the subject save that it "would not solve the problems of industrial development in New Zealand" (MEC 1962, p.34). Holmes' (1966, p. 13) motivation was to breach the bastion of existing trade controls by exposing local producers to more competition in a larger regional market; this potentially reduces the extent to which "further import substitution is pushed behind a wall of protection... within the confines of a relatively small market" and makes it less likely "we...prejudice the development of our existing export industries, and of our industries and services generally, by raising their costs of production". An extensive academic debate ensued (Ian McDougall 1966 summarises the main issues). As was quite usual during the 1960s and 1970s, the costs of dis-intervention, of

\footnotetext{
${ }^{31}$ Blyth speculated that it would take a $30-40 \%$ average effective tariff on imports to make a major difference to the long-term trend rates of industrialisation and employment in manufacturing (p.23).
} 
even slightly reforming the external barriers, figured disproportionately in the discussion (e.g. short term employment losses, specific firms that might not survive etc). Affected interest groups weighed heavily in the debate. McDougall grants the validity of their position: "on equity grounds, it is difficult to deny that capital and labour which has been induced by government policy to locate in inefficient industries is deserving of adequate compensation if the industries concerned are to be eliminated by [Trans Tasman] competitive forces" (p. 53). In the event, the creation of a quite limited free trade area under NAFTA in 1965 and the far more open, free trade CER agreement in 1983, both gave a series of demonstration and discovery effects confirming the fertility of Holmes' early contributions on this subject (Lloyd 1984). ${ }^{32}$

The Task Force on Economic and Social Planning (1976) made up of several leading economists and chaired by an academic economist (Holmes) uncritically accepted the old Bretton-Woods type shibboleths - an immutable foreign exchange constraint, a fixed, adjustable exchange rate and controls on capital account. This acceptance took place without consideration of academic work arguing in favour of alternative external arrangements predicated on a flexible or floating exchange rate and more open capital account (McCann 1969). ${ }^{33}$ Ewen McCann was merely relating the basic textbook lesson that NZ's foreign exchange constraint was self imposed, not an exogenous factor; it could be removed at once with new external policy settings. ${ }^{34}$ While making some ground in suggesting wider use of market prices and moving towards 'liberalisation' of the economy, the Task Force vacillated. Reminiscent of the 1950s, it sketched a picture of pessimism concerning the supply ("physical limitations") and demand ("income elasticities") for traditional NZ exports. In these conditions "conservation of foreign exchange" was paramount and may legitimately be "achieved by regulating import volumes" over the "short run" (Task Force 1976, pp. 195-7). There is no recognition given to NZ's long experience from 1938 of using quantitative import regulations ostensibly as 'short run' instruments only to find that they generated negative unintended consequences. These instruments not only degraded price signals; they

32 As Holmes (1994, p. 16) commented much later with some satisfaction: "a significant number of New Zealand manufacturers discovered that they could compete quite effectively with Australians". He noted that the 4:I ratio in the balance of trade with Australia in the early 1960s had reached an even balance by the 1990s.

33 The old Bretton Woods-type intellectual consensus on the exchange rate and capital account did not seem to breakdown until the early 1980s. Paul Wooding's (1982) review article of Dean, Nicholl and Walsh (1981) illustrates that an intellectual shift had occurred in external economic policy at the RBNZ toward views earlier anticipated by the publications of academics e.g. McCann (and Allan Fisher in the 1930s).

${ }^{34}$ Here we refer to basic texts in international finance, though as Blyth (2004, p. 59) reports, in Auckland at least, a separate course in international finance did not appear on the list of subjects taught until 1985. 
created entrenched vested interests and therefore became exceedingly difficult to withdraw. In short, the political costs of dis-intervention kept rising.

It took an expatriate academic on a research visit to $\mathrm{NZ}$ in the late 1970s squarely to confront the above conclusion. Like many academic economists before him, Peter Lloyd (1978) repeated the need for major trade policy reforms in order to make necessary changes in government expenditures on industry assistance and protection both to achieve pressing fiscal targets and generate long-term structural adjustments in an economy experiencing persistently low growth. With growth opportunities at the forefront, he applied these views in a study of NZ's long-term trade problems and trade policy framework (Lloyd 1980). Originally a student in Belshaw's lectures at Victoria University, and making allowance for the different context, Lloyd reached general conclusions not all that far removed from his teacher's position in the 1930s and 1940s. In short, NZ trade policy changes in the period from the 1960s to the 1980s had been "piecemeal responses to each exigency of the economic and political situation" (p.73). (On the latter read: rent seeking). ${ }^{35}$ The changes required were "radical", including the removal of quantitative restrictions on imports, simplification of tariffs, and the overhaul of export incentives. Naturally, "producers and their employees" in activities in receipt of government assistance and protection "would resist the loss of their privileged position". However "equal assistance for all is zero assistance for all". It is proposed that policy changes move in the direction of exposing producers to relative prices and changes in those prices affecting particular industries in order that they may confront the real profitability of those activities and allocate resources accordingly (p.74). Not long after this study, the three-member Economic Monitoring Group (EMG) of the NZ Planning Council (of which two were academics - Conrad Blyth and Gary Hawke), produced reports in a similar vein (EMG 1983, 1984). They may be read as reiterations of points made by many $\mathrm{NZ}$ academic economists in previous decades, indeed as far back as the 1930s, and as primers for the policy changes that were to follow in the next decade of economic liberalisation. Perhaps emboldened by Lloyd's study they refer, for example, to the "discredited policies of import protection and export assistance" (EMG 1983, p. 50); and they elaborate on the twin realisations that "import control was originally introduced... as a balance of payments control measure but it is now a principal means of supporting the existence of a substantial part of the manufacturing sector", and export incentives "are now largely justified in terms of compensation to exporters for the costs

35 David Preston (1978, p.112) surmised that if an anthropologist from another age visited NZ in 1978 they would observe "vigorous participation of organised lobbies in the debate on policy formulation and in helping to shape the number of government interventionist activities in fields as diverse as industrial protection, wages policy, and farm income stabilization". 
imposed on them by protection given to other industries" (EMG 1984, p.7). In his personal recollection of working on these reports Blyth (2004, p.102) makes a general point about their underlying economic philosophy - a philosophy entirely consistent with Lloyd's recommendations on trade policy. Thus the EMG work

envisages a free market, private enterprise economy in which planning is undertaken principally at the level of the management of the firm, the farm and the enterprise, with the risks and consequences of decisions taken in an uncertain world being borne by management. What to produce and where to sell it is a matter for enterprise and not government.

That we could, at the end of this survey, imagine Barney Murphy writing these words in the 1920s or 1930s should scarcely be surprising.

\section{Conclusion}

We are now in a position to take a brief overview. When the Minister of Finance made a trenchant remark in 1979 that "he had no intention of letting efficient industries go to the wall for the sake of a theory" (quoted in Lattimore and Wooding 1996, p.326), he was probably expressing a view on the academic economics of trade policy also held by several Ministers of Finance since the late 1930s. That we may assume he knew the meaning of 'efficiency' and the theory of comparative advantage from which it derived, is questionable. Previous government ministers had expressed similar skepticism about the uses of economics in the formulation of trade policy. ${ }^{36}$ Malcolm McKinnon (2003, p. 170) generalizes in his history of the New Zealand Treasury that economic management in NZ in the 1930s and 1940s was mostly a practical, ad hoc political process more than a process that draws extensively on the input of 'experts' including academic economists. We would insist on extending that generalisation to encompass all the following decades up to the 1980s. Paul Wooding (1982, p.174) offers a reason for the general political rejection of ideas on economic policy offered by academic economists: it possibly "derives from the...preoccupation with theory and with simple applications of that theory without much empirical content". And David Preston (1978, p.113) claimed that the "academic economist [in NZ] who has the training to look at the larger picture, is inclined to retreat into an imaginary world and construct models of economic systems where lobbies do not hold sway". Our survey finds little support for these propositions. For instance, the work of

\footnotetext{
${ }^{36}$ Phil Holloway (1964, p.195), Labour Minister of Industries and Commerce Minister in the late 1950s writing on the subject of government assistance to manufacturing, pointed to the overriding consideration of the "politically possible" and the "immediate electoral climate" as decisive factors; Tom Shand (1962, p. 435) National Minister of Labour in the 1960s, writing in the Economic Record, judged that the criteria economists provide for policy "are woefully inadequate as a guide to action in the field of economic management".
} 
economists in the 1960s and 1970s that we have reported above contained serious attempts to use available quantitative data and measure the costs of trade policy. Certainly, in previous periods economists were handicapped by paucity of data and some of them made that problem explicit. However, they most certainly did not downplay the powerful role of interest groups.

With or without the support of applied studies, policymakers in NZ were motivated to ignore the work of academic economists from the 1930s to the 1980s, which was oriented in the direction of using market processes in formulating trade policy. More often than not, trade policy was made without the assistance of applied economic analysis using available data and without respect for the principle of comparative advantage. The long-term, economy-wide value of protection was always exaggerated. In all three periods we examined, the political economy of rent seeking gave ongoing support to the exaggerated claims for protection; for the transfer of income shares implied by various government trade policy interventions; for a persistently uneven tariff structure; import licensing; elasticity pessimism; cumbersome and administratively complicated export incentives; and for downplaying the potency of market price incentives including more frequent use of the exchange rate mechanism.

At the beginning of this paper we asked what we might learn as economists from this survey. First, Keynes's oft-quoted remark that economic ideas ultimately overcome, by a process of encroachment, the power of vested interests, does not seem all that applicable here. To be meaningful in the NZ case the time frame for "encroachment" would have to extend nearly half a century! We have demonstrated that in the NZ case of trade policy and its impacts on economic development, the principles underwriting the liberal trade policy reforms of the 1980s and 1990s were already 'in the air' as it were, in NZ economics during the 1920s and 1930s; they were further elaborated by academic economists in the decades that followed in connection with the problems that arose in different policy-relevant contexts, though to little immediate avail. The lesson here is that the abstract principles of economics may not be as important (for the making of trade policy in this case) as we might like to suppose. ${ }^{37}$ Second, the work of the academic economists exposited in this paper deserves our critical attention and appreciation because it was developed independently of political pressures; invariably

\footnotetext{
37 It may be tempting to conclude from the foregoing that the end of the period under review marked the triumph of economic analysis over sectional interests. We warn against drawing that conclusion. In the subsequent period of economic liberalization it is arguable that what actually occurred was not so much a major change in the influence of economic analysis on policy formulation as a change in the beneficiaries of rent seeking activities. An examination of the evidence on this point might yield some interesting insights into the recent history of economic policy in NZ.
} 
took a long run view of the relationship between trade and economic development; recommended a certain direction of policy reform based on sound economic principles; and was not intimately connected to the exigencies of day-to-day policymaking.

To be sure, the academic economics of trade policy may develop unrealistic expectations of what is immediately possible in trade reform. Yet a large majority of the economists whose work we have mentioned in this paper favoured open trade regimes and would not have given hostile reception to the revisions in trade policy undertaken in the 1980s and 1990s.

Academic economics keeps alive and refines ideas that may prematurely have been relegated to the scrap heap but eventually see the light of day in an applied, policy context. To answer the question posed in the title of our paper, this is just one reason why early NZ academic economics is useful.

\section{References}

Belshaw, H. (1928). The economic position of the farmer in New Zealand. In National Industrial Conference: Report of Proceedings. Wellington: Government Printer.

Belshaw, H. (1932). Ottawa’s Task. Belshaw Papers 39D.

Belshaw, H. (1933). Crisis and readjustment in New Zealand. Journal of Political Economy, $41,750-775$.

Belshaw, H. (1937). Guaranteed prices for New Zealand exports. Economic Record, 13, 168-188.

Belshaw, H. (1939a). Stabilization in a dependent economy. Economic Record 15, 40-60.

Belshaw, H. (1939b). Import and exchange controls in New Zealand. Economic Record 15, 173-186.

Belshaw, H. (1939c). Guaranteed prices in operation. Economic Record, 15, Supplement, 69-81.

Belshaw, H. (1941). Problems of reconstruction. Wellington: NZ Institute of International Affairs.

Belshaw, H. (1945). Reconstruction in New Zealand. Ninth Conference of the Institute of Pacific Relations. Wellington: NZ Institute of International Affairs.

Belshaw, H. (1947). Economic Organization. In H. Belshaw (Ed.) New Zealand. Berkeley: University of California Press and Cambridge University Press.

Bergstrom, A.R. (1949). The guaranteed price for dairy products - New Zealand. Economic Record, 25, 91-97. 
Bergstrom, A.R. (1955). An econometric analysis of the supply and demand for New Zealand's exports. Econometrica, 23, 258-276.

Bertram, G. (1988). New Zealand tariff policy between the wars. Paper presented at the New Zealand Association of Economists Annual Conference, Wellington.

Blyth, C.A. (1963). Prospects for Manufactured Exports. Wellington: NZIER.

Blyth, C. A. (1964). 'Introduction', in C. A. Blyth (Ed.), The Future of Manufacturing in New Zealand. Wellington: NZ Institute of Public Administration and Oxford University Press.

Blyth, C. A. (1974). 'The Industrialisation of New Zealand', New Zealand Economic Papers, 8, 1-22.

Blyth, C. A. (1987). 'The Economists' Perspective on Economic Liberalisation', in A. Bollard and R. Buckle (Eds), Economic Liberalisation in New Zealand. Wellington: Allen \& Unwin.

Blyth, C.A. (2004). A history of the economics department of the University of Auckland. Auckland.

Blyth, C.A. (2008). Early academic economics in New Zealand: Notes on its history from the 1870's to the 1950's. University of Auckland Working Papers in Economics No. 266. Auckland.

Blyth, N. (1983). A note on the elasticity of demand for New Zealand sheepmeat exports. New Zealand Economic Papers, 17, 117-121.

Bollard, A. \& Buckle, R. (Eds) (1987). Economic Liberalisation in New Zealand. Wellington: Allen \& Unwin.

Bollard, A., Lattimore, R., \& Silverstone, B. (1996). Introduction. In B. Silverstone, A. Bollard and R. Lattimore (Eds), A Study in Economic Reform: The Case of New Zealand. Amsterdam: North-Holland.

Brigden, J.B. et al. (1929). The Australian Tariff - an Economic Enquiry. Melbourne: Melbourne University Press.

Brownlie, A.D. (1966). New Zealand's import function. New Zealand Economic Papers, 1, $16-20$.

Buckle, R.A. (1977). The response of New Zealand pastoral exports to the 1967 devaluation. New Zealand Economic Papers, 11, 25-51.

Candler, W. (1963). How to progress backwards. The Economist, 874. (Anonymous.)

Candler, W. \& Hampton, P. (1966). The measurement of industrial protection in New Zealand. Australian Economic Papers, 5, 47-58.

Castle, L.V. (1966). A Study in New Zealand Manufacturing. Wellington: Victoria University of Wellington. 
Condliffe, J.B. (1925). The marketing of dairy produce. Canterbury Chamber of Commerce Commercial Bulletin, 2, March.

Condliffe, J.B. (1939). The International position as it affects New Zealand. Economic Record, 15, Supplement, 17-24.

Condliffe, J.B. (1950). The Teacher and his influence. In R.S. Allen (Ed.), Liberty and Learning: Essays in Honour of Sir James Hight. Christchurch: Whitcomb and Tombs.

Condliffe, J.B. (1969). The Economic Outlook for New Zealand. Christchurch: Whitcomb \& Tombs.

Copland, D. (1939). The economics of insulation. Economic Record, 15, Supplement, 2531.

Copland, D. (1960). Economic problems for New Zealand in an expanding world. Wellington: N.Z. Society of Accountants.

Corden, W. M. (1963). The Tariff. In A. Hunter (Ed.), The Economics of Australian Industry. Melbourne: Melbourne University Press.

Corden, W. M. (1966). Protection. Economic Record, 42, 129-48.

Court, R.H. (1967). Supply response of New Zealand sheep farmers. Economic Record, 43, $289-301$.

Cullen, R. \& Wooding, P.A. (1981). Export incentives in New Zealand, 1962-1978. New Zealand Economic Papers, 15, 144-162.

Dean, R.S., Nicholl, P.W.E. \& Walsh, M.J. (1981) External Economic Structure and Policy. Wellington: Reserve Bank of New Zealand.

Economic Monitoring Group (1983). Foreign Exchange Constraints, Export Growth and Overseas Debt. Wellington: New Zealand Planning Council.

Economic Monitoring Group (1984). Strategy for Growth. Wellington: New Zealand Planning Council.

Elkan, P. (1972). Industrial Protection in New Zealand 1952-1967. Wellington: NZIER.

Elkan, P (1977). The Meaning of Protection. Wellington: NZIER.

Endres, A. M. (1984). The New Zealand Full Employment Goal: 1950s to the 1980s, New Zealand Journal of Industrial Relations, 9, 33-44.

Endres, A.M. (1986). The Political Economy of W.B. Sutch: Toward a critical appreciation. New Zealand Economic Papers, 22, 17-39.

Endres, A.M. (1988). 'Structural' economic thought in New Zealand: The inter-war contribution of A.G.B. Fisher. New Zealand Economic Papers, 22, 35-49.

Endres, A.M. (1990a). The development of economists' advice policy advice in New Zealand 1930-34: with particular reference to Belshaw's contribution. Australian Economic History Review, 30, 64-78. 
Endres, A.M. (1990b). The economics of wages and wages policy in the depression and recovery period: distinctive elements in the New Zealand debate, 1931-1936. New Zealand Journal of Industrial Relations, 15, 1-18.

Endres, A.M. (1991). J.B. Condliffe and the early Canterbury tradition in economics. New Zealand Economic Papers, 25, 171-197.

Endres, A.M. (2010). Marshallian economics in New Zealand. In T. Raffaelli et al. (Eds) The Impact of Alfred Marshall's Ideas: The Global Diffusion of his Work. Cheltenham: Edward Elgar.

Endres, A.M. \& Fleming G.A. (1995). Monetary thought and the analysis of price stability in early twentieth century New Zealand. New Zealand Economic Papers, 29, 173-194.

Endres, A.M., \& Rogers, A.J. (2014). Trade policy and international finance in the Bretton Woods era: a doctrinal perspective with reference to Australia and New Zealand. History of Economics Review, 59, 62-81.

Fisher, AG.B. (1928). New Zealand wheat: A new sliding scale experiment. Economic Record, 4, 306-313.

Fisher, A.G.B. (1932a). The New Zealand economic problem: A review. Economic Record, 8, 74-87.

Fisher, A.G.B. (1932b). Sliding scales in depression: New Zealand wheat. Economic Record, 8, 262-269.

Fisher, A.G.B. (1935). The Clash of Progress and Security. London: Macmillan.

Fleming, G. (1997). Keynes, purchasing power parity and exchange rate policy in New Zealand during the 1930s depression. New Zealand Economic Papers, 31, 1-14.

Groenewegen, P., \& McFarlane, B. (1990). A History of Australian Economic Thought. London and New York: Routledge.

Hampton, P., Hudson, M.A., Miller, G.M., \& Tay, F. (1964). The Rosenberg revolution in economic theory: A comment. Christchurch: University of Canterbury.

Hampton, R.G. (1933). Export control boards in New Zealand. Institute of Pacific Relations.

Hawke, G.R. (1972). New Zealand and the International Monetary Fund. Economic Record, $48,92-102$.

Hawke, G.R. (1985). The Making of New Zealand: An Economic History. Cambridge: Cambridge University Press.

Hawke, G.R. (1987). Australian and New Zealand economic development from about 1890 to 1940. In K. Sinclair (Ed.) Tasman Relations: New Zealand and Australia 1788-1988. Auckland: Auckland University Press.

Hight J. (1928). New Zealand. In League of Nation Publications, CE129. Geneva: League of Nations.

Hight, J. (1939). Preface. The Economic Record, 15, 3-6. 
Holloway, P.N. (1964). Government policies and assistance in manufacturing development. In C.A. Blyth (Ed.), The Future of Manufacturing in New Zealand. Wellington: New Zealand Institute of Public Administration and Oxford University Press.

Holmes, F.W. (1958). The Commonwealth and a free-trade area in Europe. International Affairs, 34, 38-48.

Holmes, F.W. (1959a). Recent economic developments in Western Europe and their implications for New Zealand. Canterbury Economic Bulletin No. 410.

Holmes, F. W. (1959b). Exchange rate. Accountants Journal, 38, 74-78.

Holmes, F.W. (1960). International Arrangements Affecting New Zealand: Exports and Industrial Development. Paper presented at the Industrial Development Conference, Wellington.

Holmes, F.W. (1961). Should we have Free Trade Between Australia and New Zealand? Wellington: NZIER.

Holmes, F.W. (1962). Planning for Growth in a Freer Economy. Wellington. Sir Sydney Holland Memorial Lecture. Paper presented at the National Party Centre Hall, Wellington.

Holmes, F.W. (1966). Freer Trade with Australia? Wellington: NZIER.

Holmes, F.W. (1994). Security and competitiveness, 1935-1994: Reflections on New Zealand's External economic Strategy. Wellington: Institute of Policy Studies.

Holmes, F.W. (1996). In defence of the open economy: a personal retrospective. Wellington: NZIER.

Holt, L.W. (1939). Redemption of New Zealand debt in London. Economic Record, 15, 245-248.

Jackson, K. (1988). Tariff reform in New Zealand: A continuing search. University of Auckland Working Papers in Economics No 41.

Keynes, J.M. (1936). The General Theory of Employment, Interest and Money. London and Basingstoke: MacMillan.

King, J.E. (Ed.) (2007). A Biographical Dictionary of Australian and New Zealand Economists. Cheltenham UK: Edward Elgar.

Krueger, A.O. (1974) The Political Economy of the rent-seeking society. American Economic Review, 64, 291-303.

Krueger, A. O. (1997). Trade Policy and Development: How We Learn. American Economic Review, 87, 1-22.

Lattimore, R. and Wooding, P. (1996). 'International Trade', in B. Silverstone, A. Bollard and R. Lattimore (Eds), A Study in Economic Reform: The Case of New Zealand. Amsterdam: North-Holland.

Lloyd, P.J. (1978). Structural adjustment and trade policies. New Zealand Economic Papers, 12, 116-136. 
Lloyd, P. J. et al. (1980). New Zealand's Long Term Foreign Trade Problems and Structural Adjustment Policies. Wellington: New Zealand Planning Council.

Lloyd, P.J. (1984). New Zealand, CER and the Pacific. New Zealand Economic Papers, 12, 116-136.

Makin, K. (1983). Effective rates of subsidy to New Zealand forest exports. New Zealand Economic Papers, 17, 25-35.

McCann, E. (1969). Money and the Balance of Payments. New Zealand Economic Papers, $3,51-60$.

McCloskey, D.N. (1976) Does the past have useful economics? Journal of Economic Literature, 14, 434-461.

McDougall, I.A. (1966). New Zealand - Australia free trade agreement. New Zealand Economic Papers, 12, 116-136.

McKinnon, M. (2003). Treasury: The New Zealand Treasury, 1840-2000. Auckland: Auckland University Press.

Monetary and Economic Council (1962). Economic Growth in New Zealand. Wellington: Government Printer.

Murphy, B.E. (1939a). Dominion's New Trade Policy. New Zealand Financial Times, 9 , 638-639, 642.

Murphy, B.E. (1939b). Our secondary industries. New Zealand Financial Times, 9, 675676, 680.

Murphy, B.E. (1939c). Our Industrial Growing Pains. New Zealand Financial Times, 9, $835-836,842$.

National Industrial Conference (1928). Report of Proceedings (1928). Wellington: Government Printer.

Neale, E.P. (1934). The report of the New Zealand Tariff Commission. Economic Record, 9, 253-260.

Neale, E.P., (1938). Recent Trade Policy in New Zealand. Economic Record, 14, 83-87.

New Zealand Economic Committee (1932). Report of the Economic Committee.

Wellington: W.A.G. Skinner, Government Printer.

New Zealand Manufacturers' Federation (1963). Criteria for Industrial Development in New Zealand. Wellington.

New Zealand Treasury (1958). New Zealand Economic Survey. Wellington. Government Printer.

Philpott, B.P. (1964). The future of agriculture in the New Zealand Economy. In M.F. Lloyd-Pritchard The Future of New Zealand. Auckland: Whitcombe and Tombs. 
Popper, K.R. (1945). The Open Society and its Enemies: Vol. 1 The Spell of Plato. London: Routledge and Kegan Paul.

Preston, D. (1978). Restructuring the economy. New Zealand Economic Papers, 12, 98 115.

Rodwell, H.R. (1932). Economic aspects of empire tariff preference. Economic Record, 8, $1-18$.

Rodwell, H.R. (1936). Taxation, grants and subsidies in relation to farming. In H. Belshaw et al. (Eds) Agricultural Organization in New Zealand. Melbourne: Melbourne University Press.

Rodwell, H.R. (1959). The Place of Manufacturing in New Zealand. Sir Sydney Holland Lecture. Wellington: Ferguson and Osborn.

Rosenberg, W. (1959). Twenty-one years of guaranteed prices for butter and cheese in New Zealand. Economic Record, 35, 242-250.

Rosenberg, W. (1964). A revolution in economic theory? Economic Bulletin, No. 469.

Rosenberg, W. (1965). What every New Zealander should know about import controls and industrialization in New Zealand. Christchurch.

Rosenberg, W. (1972). Import Controls and Full Employment ... or Else! Christchurch: New Zealand Monthly Review Society.

Rowe, J.W. (1966). Import Reliance 1950-65. New Zealand Economic Papers, 1, 24-30.

Scobie, G.M. (1973). The price elasticity of demand for New Zealand exports: Theory and estimation. New Zealand Economic Papers, 7, 1-24.

Shand, T.P. (1962). Theory and practice in economic policy. Economic Record, 38, 427437.

Simkin, C.G.F. (1945). Social Engineering or Economic Collectivism? Christchurch: Caxton Press.

Simkin, C.G.F. (1946). Insulationism and the problem of economic stability. Economic Record, 22, 50-65.

Simkin, C.G.F. (1948). War time changes in the New Zealand economy. Economic Record, $24,18-29$.

Simkin, C.G.F. (1951). The Instability of a Dependent Economy. London: Oxford University Press.

Simkin, C.G.F. (1953). Investment Priorities. Conference on Capital Development in New Zealand During the Next Ten Years. Christchurch.

Simkin, C.G.F. (1962). The Limits of Competitive Enterprise in New Zealand. In C. B. Hoover (Ed.), Economic Systems of the Commonwealth. Durham NC: Duke University Press. 
Stephens, F.B. (1936). Control Boards. In H. Belshaw et. al. (Eds), Agricultural Organization in New Zealand. Melbourne: Melbourne University Press.

Stigler, G.J. (1969). Does economics have useful past? History of Political Economy 1, 217-230.

Sutch, W.B. (1936). Recent Economic Changes in New Zealand. Wellington: Institute of Pacific Relations.

Sutch, W.B. (1939). The Ottawa agreement and after. Economic Record, 15, Supplement, $32-44$.

Tariff and Development Board (1963). Criteria for Industrial Development. Wellington: Government Printer.

Tariff Commission (1927). Report: Appendices to the Journals of the House of Representatives H28, Government. Wellington: Government Printer.

Tariff Commission (1934). Report: Appendices to the Journals of the House of Representatives B3, Government. Wellington: Government Printer.

Task Force on Economic and Social Planning (1976). New Zealand at the Turning Point. Wellington: Government Printer.

Tocker, A.H. (1925). The measurement of business conditions in New Zealand. Economic Record, 1, 47-62.

Williams, D. O. (1928). The Arbitration Court and price dislocations. In National Development Conference: Report of Proceedings. Wellington: Government Printer.

Williams J., (1948). The New Zealand Economy. New York: Institute of Pacific Relations.

Winch, D. (1969). Economics and Policy. London: Hodder and Stoughton.

Wooding, (1982). The Reserve Bank and the New Zealand balance of payments (a review article). New Zealand Economic Papers, 16, 174-182.

Wooding, P. (1987). Liberalising the International Trade Regime. In A. Bollard and R. Buckle (Eds), Economic Liberalisation in New Zealand. Wellington: Allen \& Unwin.

Zanetti, G.N. (1966). The New Zealand economy 1966: The failure of policy. New Zealand Economic Papers, 1, 5-15. 